\title{
Students' Perceptions of Using Zoom Application on Mobile Phone in Improving Speaking Skills During Online Learning at Ban Loeiwangsai School, Loei Province, Thailand.
}

\author{
1Putri Karya Dwi Bawanti \\ English Education Department, Universitas Muhammadiyah Gresik, East Java, Indonesia, \\ Email : putrikarya170403@umg.ac.id \\ ${ }^{2}$ Yudhi Arifani \\ English Education Department, Universitas Muhammadiyah Gresik, East Java, Indonesia, \\ Email :yudhi_arif@umg.ac.id
}

\begin{abstract}
This study focused on the impact of using the Zoom application on mobile phones by examining students' perceptions of speaking skills and their attitude during online learning. The students have 4 months of experience using the Zoom application. This research method used a survey design and collects data by giving 12 questionnaire items through Google form to students. The participants are elementary school students with 3 categories, namely grade 4, grade 5 and grade 6 at Ban Loeiwangsai school, Thailand. The findings of this study are that the strategic design of online learning on the use of the Zoom application has an impact on students performance in independent learning and managing time. This also has an impact on the ability and knowledge of students learning English especially in the speaking skill. Their academics are particularly affected by the use of the Zoom application during online learning.
\end{abstract}

Keywords: online learning, zoom application, speaking skill

\section{Introduction}

Corona virus disease has become an epidemic that affects the entire world today, including the world of education. Because of corona, the government issued a policy that schools be conducted online. Which means that teaching and learning activities are carried out in their respective home. With this policy, this situation becomes a new challenge for teachers especially in Ban Loeiwangsai school in Loei province, Thailand. Because this activity is carried out online, of course there are several problems faced by teachers and students at Ban Loeiwangsai school, including sometimes bad signals that interfere with the process of teaching and learning process, lack of understanding of the material presented by the teacher because it is not conveyed well, and etc. In addition, there are also several problems faced by the students at that school which include lack of vocabulary, mispronounced vocabulary, and lack of confidence when they speak English. Students may find difficulties in developing EFL English speaking skills due to the language complexity (Nunan, Second Language Teaching \& Learning, 1999). Difference between mother tongue and English make uncomfortable when speak in front of the people with a new language (Ellis, 2008), and the most important cause rather to practice the language and in different contexts. (Shumin, 2002). While studying EFL at General and speaking skills in particular are quite demanding, the students at Ban Loeiwangsai School proved that they still have low progress in learning speaking.

English is the international language. In language, speaking skill is needed as a tools of communication. Speaking is a productive skill that can be directly and empirically observed; those observations are invariably colored by the accuracy and fluency (Brown, 2004). Speaking is activity that can express our thought and feeling orally. Therefore, speaking skill is important things to learn. At this 
time, technology plays a greater role in almost all activities including teaching and learning activities especially because it is currently being hit by the corona virus. Because of the impact of corona virus, many students in Ban Loeiwangsai school need an understanding of speaking include how to pronounce the words correctly, how to speak fluently and other aspects. So, the teacher can take advantage of technology in teaching English, especially for teaching speaking. There are several applications available on mobile phones which can be used for learning, such as Line, WhatsApp, Zoom, Telegram, and many others. One of the popular technologies today is Zoom application on one of mobile phones. Zoom is a service cloud computing based video conferencing. Zoom application allows users to meet each other virtually. More interesting application, Zoom has a recording facility automatic activity during executing video conferencing so that it can be made activity documents that will later be obtained back can be viewed or played back if needed. Compared with other application, Zoom has several advantages, one of them is this technology has the potential to bridge space, time, as well as students' flexibility time in their learning process. Seeing the problems that happen in students of Ban Loeiwangsai school above, researcher took the initiative to test the effectiveness of the Zoom application in conducting learning. The Zoom application effectiveness test can be a reference for the teacher to be able to provide guidance and training speaking skill through the Zoom application. This study was conducted to determine students' perceptions of using Zoom application on mobile phones in improving speaking skills during online learning at Ban Loeiwangsai school, Thailand.

\section{Literature Review}

\section{Online Learning}

The definition of 'online learning' is very broad but has various meanings. Online learning is broader than 'network learning'; while network learning focuses on human relations (Banks et al. 2003; De Laat et al. 2007), online learning lacks such specificity. It is narrower than 'eLearning' and 'digital education' ones includes a variety of digital tools and resources, not only the internet and focus on digital competency development. In addition, online learning does not have built in ones claims developmentsyet that make technology enhanced learning' (TEL) (Laurillard \& Masterman 2010; Kirkwood \& Price 2014) problems on phrases (Bayne 2014). In our post-digital reality, one could argue that 'online' is no longer a useful description for real student experiences (Fawn 2019), especially in rich parts of the world, where Internetconnected devices are regularly used, and restrictions in between learning and a series of other activities in everyday life becomes so easy. It means that the delivery of all kinds of content through all media technology, including the Internet, audio / video, and others. Online learning is focused on some aspects including various online contexts, computer-based learning and delivery methods, types, formats and media such as multimedia, educational programming, simulations, games and mobile media use.

According to several studies that have been published, Dabbagh \& Bannan Ritland (2005) studied Online Learning: Concepts, Strategies, and Application, they found there are differences between traditional and online learning environments. They argued that traditional learning environments are (a) bound by the location and whereabouts of instructors and students, (b) presented in real time, (c) controlled by the instructor and (d) linear in teaching methods. Using developing information and communication technology, real-time information, online teaching and learning environment unbound and dynamic. The online learning environment includes a wide range of pedagogical and practice often characterized by active learning of student-centered pedagogical techniques (Baker, 2003; Browne, 2005). Rapanta et al., (2020) reported Online University Teaching During and After the Covid-19 Crisis: Refocusing Teacher Presence and Learning Activity.

\section{Speaking skill}

According to Brown (2004), speaking is a productive skill that can be in direct and emperical observed; accuracy and fluency are invariably colored observations. Speaking is activity that can express our thought and feeling orally. Brown (2007: 237) states that social contact in interactive language functions is a key in which is how you say it, what you convey with language of body, gestures, eye contact and other non verbal 
message. So, speaking is capability to express the articulation of sound or to deliver thought and opinion to the others with body language, gestures, and eye contact. Beside that, Students may find difficulties in developing EFL English speaking skills due to the language complexity (Nunan, Second Language Teaching \& Learning, 1999). Difference between mother tongue and English make uncomfortable when speak in front of the people with a new language (Ellis, 2008), and the most important cause rather to practice the language and in different contexts. (Shumin, 2002). While studying EFL at General and speaking skills in particular are quite demanding, the students at Ban Loeiwangsai School proved that they still have low progress in learning speaking.

Baniabdelrahman, (2013) reported Effect of Using Internet Tools on Enhancing EFL Students' Speaking skill. The study is a quasi experimental one with two independent variables (The method of teaching and gender) and one dependent variable (students' scores in the speaking post-test). He found that the use of oral dairies with the first year university students helped significantly to increase their participation and their motivation in English classes. Participation of students in the classroom is a reflection of strong motivation toward learning. Harmer (2007, p. 343) stated that speaking is a complex skill because at least it is concerned with components of grammar, vocabulary, pronunciation, fluency and comprehension. Here are important components in speaking skill; a) Grammar. Grammar is a set of rules that explain how we use a language. The aim of grammar is also to learn the correct way to acquire language skills in both written and spoken form. Therefore, grammar is a thing that takes students to compose the correct sentence in a conversation. b) Vocabulary. Vocabulary means the appropriate diction that is used in communication. Lack of vocabulary, it is difficult build a sentence to communicate effectively or express idea in oral and written form. c) Pronunciation. Pronunciation is a way for speaker to produce sound or language when the speaker are talking. It is concerned with the phonological process which refers to the grammatical component consisting of the elements and principles that determine the variation of sounds and patterns in a language. A speaker who is constantly mispronouncing various phonemes can be very difficult for speakers of other languages to understand the point. d) Fluency. Fluency can be term as the ability to speak fluently and accurately. Fluency in speech is the goals of many people learn the language. Signs of fluency include a fairly fast speaking rate and only a small number of pauses like "emm" or "errrr". These signs indicate that the speaker does not need to spend a lot of time looking for language items necessary to express the message. e) Comprehension. Comprehension is also an important component in speaking. Comprehension is the power training to understand the actions of the mind that aim to increase understanding in conveying something. These are four components of speaking that must be considered by students if they want to speak well.

\section{Zoom Application}

With the prevailing policy that teaching and learning activities are carried out at home, almost all teachers and students change direction by changing all learning methods carried out online. One of the most popular applications is the Zoom application. Zoom is a service cloud computing based video conferencing. Zoom application allows users to meet each other virtually. More interesting application, Zoom has a recording facility automatic activity during executing video conferencing so that it can be made activity documents that will later be obtained back can be viewed or played back if needed. Meanwhile, Archibald et al. (2019) studied the suitability of using Zoom for qualitative data collection within a health research context. Data were collected using qualitative interviews online with 16 female nurses. The duration of the interviews was around 50 until 92 minutes. The researchers found that $69 \%$ of the participants like using Zoom as an interviewing technique in comparison Face-to-Face (FTF), mobile phone or any other videoconferencing platforms. In addition, the participants reported there are advantages of using Zoom for qualitative interviewing such as rapport, convenience, simplicity and user-friendliness. The researchers found that using Zoom might serve as a highly suitable platform in collecting data of qualitative interview. They identified the following reasons for that: relative ease of use, effectiveness of cost, data of management features, and security options. Although zoom has its advantages, besides that zoom also has disadvantages. Disadvantages of using Zoom includes there was a problem connecting. Despite finding Zoom to be intuitive, few participants did having trouble keeping up with the session. The difficulties of typical technical include low Internet bandwidth, outdated hardware, or limited webcams and / or microphones. 
Call quality and reliability issues. Some of the participants reported issues with video or audio quality during the meeting using the zoom. This incident may have happened because unreliable internet connection or usage mobile device, resulting in disconnected calls, lost call connections, or lag. Distraction is sometimes caused by an inadequate housing or participant office settings. Setup issues including bad web-cam functionality, software mismatch, low device battery, or problems with audio (e.g. sound cannot be heard without using headphones). Apart from some of the problems above, another problem is because the participants do not understand how to use Zoom rather than the technology itself. Other studied that has been published, Serhan, (2020) investigated Transitioning from face-to-face to remote learning: Students' attitudes and perceptions of using Zoom during COVID-19. This study using survey and questionnaire. The result shows that students are not completely satisfied with their learning experience during this transition period. Many factors that may have contributed to the results of this study include difficulty accessing the Zoom application. Therefore, the instructor must prepare well what will happen when using the new platform and the design of alternative activities and delivery methods.

Beside that the Zoom application also has a good impact on the students academy, this can be seen from several studied. Mohammad et al., (2020) studied about Students' Perceptions of E-learning platforms (Moodle, Microsoft Teams and Zoom platforms) in The University of Jordan Education and its Relation to self-study and Academic Achievement During COVID-19 pandemic. The method was using survey and online questioner form. The result shows that e-learning uses Moodle, the Microsoft team and The Zoom platform during the COVID-19 pandemic was well known to respondents and had a positive impact and students can do task by rely on themselves more effectively. Therefore students in universities usually have a clear understanding the context of the material that they learn and they are ready to study with several courses on Moodle, the Microsoft team and the Zoom platform and they had no trouble when using it. Hassan et al., (2020) examined the students' perceptions of using Zoom Meet Webinar during Covid- 19 Pandemic in Technical and Vocational Education. This study employed a quantitative approach using a set of questionnaires. He found that the use of Zoom meet application in online learning can help students. Addition, educators also can create and build their knowledge which to some extent was able to provide an interesting and more effective learning approach. Encouraging the use of Zoom meet application among students will have a positive impact, because it is a medium that can heal involving students, especially in giving group assignments regardless of the constraints of distance and time which means physically.

\section{Methodology}

This research was conducted at Ban Loeiwangsai school in Thailand for 4 months at 3 levels covering grade 4 consisting of 12 students, grade 5 consisting of 9 students and grade 6 consisting of 8 students with a total of 29 students. A survey has conducted. The questionnaire was developed into 12 items with a multi-point questionnaire format or Rating-Scale. Survey answer scale 'yes' and 'no'. The questionnaire was designed to measure students 'attitudes towards using zoom application and students' perceptions of the impact of zoom on improving their speaking skills. The participants were asked to fill out a questionnaire that was distributed online via a Google form.

\section{Data Collection}

Data collection was carried out through a Google form questionnaire and all questionnaires were filled in and evaluated using SPSS software. This is because the questionnaire can be completed in a short time. A number of observations used for the purpose of explaining descriptive statistics, to give understanding to people fundamental characteristics of the data. Frequency, average, standard deviation and simple linear regression test are the most commonly used descriptive for data analysis.

\section{Result and Discussion}

The responses collected from the survey items Ranking-scale were grouped into two categories: students 'attitudes towards the use of the Zoom application and students' perceptions of the impact of using the Zoom application in improving their speaking skills. In the following discussion there are only two survey answer 'yes' and 'no'. 
Table 1. Students' attitudes towards using Zoom application

\begin{tabular}{|r|c|c|}
\hline \multicolumn{1}{|c|}{ Statements } & Yes & No \\
\hline $1 . \quad$ I like to study online alone so I feel confident & $72.4 \%$ & $27.6 \%$ \\
\hline $2 . \quad$ Zoom application gave increased my ability to manage time of studying & $82.8 \%$ & $17.2 \%$ \\
\hline 3. & Online learning using Zoom application increased my motivation for \\
studying & $86.2 \%$ & $13.8 \%$ \\
\hline 4. I enjoyed using Zoom application during the class & $96.6 \%$ & $3.4 \%$ \\
\hline
\end{tabular}

To provide answers to research in the table 1 about students' attitudes towards using Zoom application. $72.4 \%$ where the result showed that students like studying online alone so that it can increase selfconfidence, $82.8 \%$ students showed that the Zoom application improves their ability to manage study time, on the other hand $86.2 \%$, online learning using the Zoom application increased students' motivation for studying. In addition, $96.6 \%$ indicated that online learning using Zoom application contributed to making learning enjoyable. Some students argued that online learning using the Zoom application makes learning English fun, therefore they become enthusiastic in learning speaking.

Table 2. Students' perceptions of the impact of Zoom application in improving their speaking skills

\begin{tabular}{|c|c|c|}
\hline \multicolumn{1}{|c|}{ Statements } & Yes & No \\
\hline 5. Zoom application contributes to make my learning faster & $86.2 \%$ & $13.8 \%$ \\
\hline $\begin{array}{l}\text { 6. I study online using Zoom application alone I remember some } \\
\text { vocabularies better. }\end{array}$ & $72.4 \%$ & $27.6 \%$ \\
\hline $\begin{array}{l}\text { I prefer online speaking assignment so that I can do it myself without any } \\
\text { help from others }\end{array}$ & $75.9 \%$ & $24.1 \%$ \\
\hline 8. I don't face difficulties in answering teacher's questions & $96.6 \%$ & $3.4 \%$ \\
\hline 9. Online learning using Zoom application I can understand the lessons easily & $93.1 \%$ & $6.9 \%$ \\
\hline 10. Online learning using Zoom application increase my learning & $79.3 \%$ & $20.7 \%$ \\
\hline 11. I study online using Zoom alone I remember lessons better. & $82.8 \%$ & $17.2 \%$ \\
\hline 12. Online learning using Zoom improving my speaking skills & $93.1 \%$ & $6.9 \%$ \\
\hline
\end{tabular}

Table 2 about students' perceptions of the impact of the Zoom application in improving their speaking skills shows that $86.2 \%$ of students who did online learning with the Zoom application helped increase their learning speed and $72.4 \%$ of students could remember the details of some of the vocabulary they had learned with better when they learn online using Zoom application itself and $75.9 \%$ of students prefer online speaking assignment when they do it their self without any help from others. This finding shows that $96.6 \%$ of students do not find it difficult to answer some questions from the teacher using English. Online learning with the Zoom application makes students understand the lesson easily with the result shown is $93.1 \%$. The result has been obtained, namely $73.9 \%$ of students learning online using Zoom application increase their interest in learning and make them study by their self and they can achieve progress in their speaking ability. Students when learning online using the Zoom application themselves are more able to remember lessons better with the shown results of $82.8 \%$. The results also showed that $93.1 \%$ of students when they studied 
online using the Zoom application were able to improve their speaking skills. The purpose of this study was to determine students' opinions about the effectiveness of the online learning Zoom application and its effect on independent learning and student academic achievement and improving speaking ability. Reviewing this data it can be concluded that the Zoom application is good for teachers and students to use in teaching and learning activities. Most students feel that the Zoom application is important for current and future activities because the Zoom application is a tool used for learning activities and the Zoom application can help them handle the learning process more effectively by using technology on mobile phones. The Zoom application can also make communication improve between teachers and students because it has access to do video conferencing anywhere and anytime. The results showed that the quality of the Zoom application curriculum at the current education level can be used in all learning topics, especially in learning English, for speaking aspects and the Zoom application can be accessed anytime. So that for users, for most students, they are able to manage their time well. The results show that the Zoom application helps students develop on their own independent study skills and motivates them to learn. The Zoom application helps them remember lessons well even though learning English is a bit difficult but they enjoy learning English, especially speaking online and prefer to study at home using the zoom application. The results show that the Zoom application encourages students to try to learn how to concentrate and makes students feel that learning speaking online is not as difficult as they imagine, even learning independently makes them more confident in trying to speak using English. So that they don't find it difficult to answer online questions given by the teacher. In addition, the Zoom application also helps students improve their ability to remember vocabulary that they have learned more because learning is done independently at home. By using the Zoom application online, students can improve their speaking skills. From the data found above are consistent with several previous studies, which confirm this use technology causes, most of the time, to increase student motivation and greater class participation (Ilter, 2009; Wu, Yen and Marek, 2011).

\section{Conclusion}

The results of the study show that online learning using the Zoom application during the COVID-19 pandemic is well known to respondents and has a positive effect which has an impact on independent learning and makes students feel more confident and able to manage the time this is shown in use of the Zoom application which also has a great influence on student action. That can be seen from the students feeling more confident when learning by themselves and having the courage to answer questions given by the teacher in English. They also show that learning to use the Zoom application is more efficient and better able to absorb learning, especially learning specifying. The finding showed that students can rely on themselves to do assignments more effectively. Researcher may argued that students at Ban Loeiwangsai School, Thailand have a fairly clear understanding and are able to improve their speaking skills. Hopefully this can make students improve their ability to speak English and learn more about English in the future.

\section{REFERENCES}

Archibald, M. M., Ambagtsheer, R. C., Casey, M. G., \& Lawless, M. (2019). Using Zoom videoconferencing for qualitative data collection: perceptions and experiences of researchers and participants. International Journal of Qualitative Methods, 18. https://doi.org/10.1177/1609406919874596.

Baker, A. (2003). Faculty development for teaching online: Educational and technological issues. The Journal of Continuing Education in Nursing, 34(6), 273-278.

Baniabdelrahman, A. A. (2013). Effect of using internet tools on enhancing EFL students' speaking skill. Journal of Contemporary Research American International, 3(6), 79-87. http://www.aijcrnet.com/journals/Vol_3_No_6_June_2013/11.pdf 
Banks, S., Goodyear, P., Hodgson, V. \& McConnell, D. (2003). Introduction to the special issue on advances in research on networked learning. Instructional Science 31: 1-6.

Bayne, S. (2015). What's the matter with 'technology-enhanced learning'? Learning, Media and Technology, 40(1), 5-20. https://doi.org/10.1080/17439884.2014.915851.

Brown, H. Douglas, (2004). Language Assessment: Principles and Classroom Practices, (San Francisco: Longman, 2004).

Browne, E. (2005). Structural and pedagogic change in further and higher education: A case study approach. Journal of Further and Higher Education, 29(1), 49-59

Dabbagh. N., \& NannaRitland, B. (2005). Online learning: Concepts, strategies and application. New Jersey, NJ: Upper Saddle River.

De Laat, M., Lally, V., Lipponen, L., \& Simons, R.-J. (2007). Online teaching in networked learning communities: a multi-method approach to studying the role of the teacher. Instructional Science, 35(3), 257-286. https://doi.org/10.1007/s11251-006-9007-0

Ellis, R. (2008). The Study of Second Language Acquisition. Oxford: Oxford University Press.Gardner, R. C. and Lambert, W. E., 1972. Motivational variables in second language acquisition. Canadian Journal of Psychology, 13, pp. 266272.

Fawns, T. (2019). Postdigital education in design and practice. Postdigital Science and Education, 1(1), 132- 145. https://doi.org/10.1007/s42438-018-0021-8.

Hassan, A., Tun, U., Onn, H., Ariffin, A., Tun, U., Onn, H., Ahmad, F., Tun, U., Onn, H., Hamzah, N., Tun, U., \& Onn, H. (2020). Students' Perceptions of Using Zoom Meet Webinar During COVID19 STUDENTS ' PERCEPTIONS OF USING ZOOM MEET WEBINAR DURING COVID-19 PANDEMIC IN. Journal Of Critical Reviews, 7(November), 5853-5858.

Ilter, B. G. (2009). Effect of Technology on motivation in EFL classrooms . Turkish Online Journal of Distance Education, 6488(10).

Kirkwood, A., \& Price, L. (2014). Technology-enhanced learning and teaching in higher education: what is 'enhanced' and how do we know? A critical literature review. Learning, Media and Technology, 39(1), 6-36. https://doi.org/10.1080/17439884.2013.770404.

Laurillard, D., \& Masterman, E. (2010). TPD as online collaborative learning for innovation in teaching. In J. O. Lindberg \& A. D. Olofsson (Eds.), Online learning communities and teacher professional develop- ment: methods for improved education delivery (pp. 230-246). Hershey: IGI Global.

Mohammad, R., Masadeh, T., World, T., Science, I., \& Fakhouri, H. (2020). Students ' Perceptions of Elearning platforms ( Moodle, Microsoft Teams and Zoom platforms ) in The University of Jordan Education and its Relation to self-study and Academic Achievement During COVID-19 pandemic . 1- Introduction. Advanced Research \& Studies Journal, 11(5), 21-33.

Nunan, D. (1999). Second Language Teaching \& Learning. Boston, Massachusetts: Heinle \& Heinle . Nunan, D. (1995). Closing the gap between learning and instruction. TESOL Quarterly, 29(1), 133158 .

Serhan, D. (2020). Transitioning from Face-to-Face to Remote Learning: Students' Attitudes and Perceptions of using Zoom during COVID-19 Pandemic. International Journal of Technology in Education and Science, 4(4), 335-342. https://doi.org/10.46328/ijtes.v4i4.148 
Shumin, K. (2002). Factors to consider: developing adult EFL students' speakingabilities. In C. J. Richards, \& W. A. Renandya, Methodology in Language Teaching (pp. 204-211). New York: Cambridge University Press . Thomas, M. (2009). Producing Cell Phone Video Diaries. In M. Thomas'Handbook of Research on Web 2.0 and Second Language Learning (pp.260 -272). Idea Group Inc (IGI).

Wu, W.-C., Yen, L. L., \& Marek, M. (2011). Using online EFL interaction to increase confidence motivation and ability. Educational Technology Society, 14(3), 118-129 . 